https://doi.org/10.46291/ISPECIJSSHvol4iss5pp493-510

\title{
Zihin Alışkanlıklarının Kullanımına Yönelik Web Destekli İngilizce Öğretiminin 9. ve 10.Sınıf Öğrencilerinin Tutumlarına ve Akademik Başarılarına Etkisi
}

\author{
Merve ERIN \\ Müdür Yardımcısı, Hasan Celal Güzel A.İ.H.L., mmerveerinn@ gmail.com, ORCID: 0000-0002-3944-4

\section{Özden DEMIRKAN}

Doç.Dr.,Gazi Üniversitesi, oozden@gazi.edu.tr

\section{ÖZET}

Bu çalışma, Costa ve Kallick (2008)'in belirlediği 16 zihin alışkanlığından; farklı öğrenme stillerine sahip öğrencilerin, yabancı dil öğrenirken başarı, motivasyon, hazır bulunuşluk ve öğrenmeye ilişkin tutumlarının olumlu bir şekilde geliştirilmesinde aktif rol oynayan (Demirel, 1990; Paker, 2006; Acat\&Demiral, 2002; Chou ve Wang, 2000; June, Chun-Sheng ve Chang 2003; Kettanurak, Ramamurthy ve Haseman, 2001; Pat, 2000; Reed, 1994) dört tanesinin kullanımına yönelik web destekli İngilizce öğretiminin 9. ve 10.sınıf öğrencilerinin tutumlarına ve akademik başarılarına etkisini göstermektedir. Araştırma, nicel modelde ve tekrarlı ölçümler desenindedir. Katılımcı grubunu Ankara ili Çankaya ilçesi Hasan Celal Güzel Anadolu İmam Hatip Lisesi'nde 2019-2020 Eğitim öğretim y1lında 9. ve 10.sınıfta okuyan toplam 36 öğrenci oluşturmaktadır. Çalışmanın öncesinde ve sonrasında öğrencilere İngilizce dersine yönelik tutum ölçeği ve başarı testi uygulanmış; testlerden elde edilen ortalama puanlar arasında anlamlı bir fark olup olmadığı incelenmiştir. Verilerin analizinde SPSS 15 programından yararlanılarak betimsel istatistikler ve bağımlı örneklem t-testi yapılmıştır. Analizler sonucunda tutum ve akademik başarı ön test/son test ortalama puanları anlamlı bir fark göstermiştir, Bu doğrultuda; 9. ve 10.sınıf İngilizce dersi için tasarlanan zihin alışkanlıklarının kullanımına yönelik web destekli öğretimin öğrenciler üzerinde olumlu etkiler yarattığı, derse karşı olumlu tutum geliştirmelerini sağladığı ve akademik başarıyı da artırdığı söylenebilir.

Anahtar sözcükler: Zihin alışkanlıkları, İngilizce öğretimi, Yabancı dil öğretimi, Web destekli öğretim.

Year 4/ 2020, Volume-4, Issue-5 | www.ispecjournal.org 


\title{
The Effect of Web-Assisted English Teaching, Based on Using Habits of Mind, on the
} Attitudes and Academic Achievements of $9^{\text {th }}$ and $10^{\text {th }}$ Grade Students

\begin{abstract}
The purpose of this study is to measure the effect of Web-assisted teaching, based on using Habits of Mind, which designed for 9th and 10th grade English lesson on students' attitudes and academic success. The research has been carried out with quantitative method and repeated measures analysis. Participants are 36 students who are studying at Hasan Celal Güzel Anatolian Imam Hatip High School in Çankaya, Ankara. Both before and after the study, an attitude scale towards English lesson and an achievement test were applied to the students. It has been examined whether a significancy exists or not between the means acquired from the tests. In the data analysis, descriptive statics and paired sample t-test have been made by SPSS 15 programme. According to the Attitude Scale results, there is a positive increasing and a significancy between the mean of pre-test and the post-test. Also there is a significancy between the mean of academic achievement tests. Consequently, it could be said that web-assisted English teaching has been made positive impacts on the students' attitudes toward English lesson and also improved their academic success significantly.
\end{abstract}

Key words: Habits of mind, English Language Teaching, Foreign Language Instruction, Web-assisted Teaching

\section{GİRIŞ}

"Bilim ve teknolojinin hızla geliştiği dünyamızda, çağdaşlaşmanın temel amacı, evrensel standartlara, evrensel bilgi ve değerlere erişebilmektir." (Tok \& Arıbaş, 2008). Teknolojik gelişmelerin bu kadar hızlı yaşanması, teknolojinin dilini de öğrenmeyi zorunlu kılmıştır (Haznedar, 2010). Çağın teknolojisini, bilimi öğrenmek, anlamak, sahiplenmek ve üretmek zorunda olan ülkemizde bu durum Avrupa Birliği üyeliği süreci de göz önüne alınarak diğer ülkelere kıyasla daha büyük önem arz etmektedir (Çelebi, 2006). Bilgi ve teknoloji çağı diye adlandırılan günümüzde internet vb. imkanlar sayesinde mesafeler kısalarak dünyanın farklı noktalarından insanlar çevrimiçi ortamlarda kolayca bir araya gelebilmekte ve bu durumda bireylere anadilleri artık yetmemektedir (Soyupek, 2007).

\section{Yabancı Dil Öğretimi}

İlköğretim ve ortaöğretim kurumlarına ait öğretim programlarında yabancı dil dersi zorunlu bir ders olmuştur. Yabancı dil öğretmenin amacı, öğrencilerin anadilleri dışındaki herhangi bir dili günlük hayatta kullanabilir seviyeye taşımaktır (Tok \& Arıbaş, 2008). Yabancı dil (İngilizce) öğrenmeye yönelik ihtiyaçlar çok iyi bilinmesine rağmen; ilköğretimden yükseköğretime kadar hiçbir düzeyinde istendiği gibi gerçekleştirilememektedir. Bu durumun Year 4/ 2020, Volume-4, Issue-5 | www.ispecjournal.org 
nedenlerine bakıldığında genel olarak öğretmen yetersizliği, fiziksel imkanların eksikliği ve öğrenci motivasyondaki düşüklük olarak üç başlık çıkarılabilir (Paker, 2006). Acat \& Demiral (2002) tarafından yapılmış araştırma ve gözlemlere dayanarak derste motive olamayan öğrencilerin yabancı dil öğrenmede de başarılı olamadıkları ifade edilebilir. Öğretmenlerin geleneksel yöntemleri daha fazla benimseyerek modern yöntemleri kullanmamaları ve hatta bazılarını hiç bilmemeleri sorunu daha net biçimde gözler önüne sermektedir (Paker, 2006).

Öğrenme, öğrencinin öğrenmeyi gerçekten istemesi durumunda gerçekleşir ve bu durumda öğrencinin ihtiyaç ve beklentileri öğretmen tarafından bilinmeli ve karşılanmalıdır (Acat \& Demiral, 2002). Özellikle yabancı dil öğretimde hedeflenen düzeye erişmek için ilk başta yapılması gereken şey o dili öğreten kişilerin mesleki ve kişisel gelişimlerinin sağlanmasıdır (Atay, 2004). Demirel (1990) yabancı dil öğretimindeki temel ilkeleri aşağıdaki gibi 10 maddede ifade etmiştir:

"1. Dört temel beceriyi geliştirme,

2. Öğretim etkinliklerini önceden planlama,

3. Basitten karmaşığa, somuttan soyuta doğru öğretme,

4. Görsel ve işitsel araçları kullanma,

5. Anadili sadece gerekli durumlarda kullanma,

6. Bir seferde tek bir yapıyı sunma,

7. Verilen bilgilerin günlük yaşama aktarılmasını sağlama,

8. Öğrencilerin derse etkin olarak katılımını sağlama,

9. Bireysel farklılığı dikkate alma

10. Öğrencileri güdüleme ve cesaretlendirme" (akt Paker, 2006).

Vygotsky; öğrenenlerin bilgiyi farkı yöntemlerle, rehber eşliğinde ve sosyal bir ortamda yapılandırdığını ifade etmiştir (Çelen \& Vural, 2009). Yabancı dil öğretimine yönelik ortamların teknolojiyle uyumlu biçimde donatılmış olması gerekmektedir (Bağçeci, 2004). Öğrenme ve öğretme sürecine uygun düzenlenen ortamlar farkl1, üretici ve yaratıc1 aktivitelerle çeşitlendirilebilir (Ergür, 2002). Ülkemizde kullanılan yabancı dil müfredatının yoğun içeriğì, öğretmenlerin bu tür aktivitelere zaman ayıramamasına neden olabilmektedir (Aydoğan \& Çilsal, 2007). Bu nedenle, genelde kağıt üzerinde yapılan gramer içerikli 
alıştırmalar ve ders kitabına dayalı uygulamalarla yabancı dil öğretimi geleneksel yöntemin dışına çıkamamaktadır (Paker, 2006).

\section{Yabancı Dil Öğretim Yöntemleri}

Avrupa Konseyi Modern Diller Bölümü tarafından dil öğretiminde yaygın biçimde kullanılan yabancı dil öğretim yöntemleri şöyle sıralanmıştır (Memiş \& Erdem, 2013):

\section{- Dilbilgisi-Çeviri Yöntemi (Grammar-Translation Method)}

$\mathrm{Bu}$ yöntemin amacı bir dilin kurallarını öğretmek ve bu kurallar sayesinde doğru çeviriler yapabilmektir.

\section{- Direkt Yöntem/Dolaysız Yöntem (Direct Method)}

$\mathrm{Bu}$ yöntemde öğrencilerin dikkatini sözel ya da görsel yöntemlerle derse çekmek önemlidir.

\section{- Doğal Yöntem (Natural Method)}

Bir bebeğin doğduğu topraklara ait dili öğrenmesi gibi yalnıza hedef dile maruz bırakılarak öğretilmesini hedefleyen yöntemdir.

\section{- İşitsel-Dilsel Yöntem (Audio-Lingual Method)}

Dinleme becerisini geliştirmeyi amaçlayan ve hedef dildeki diyalogları esas alan bir öğretim yöntemidir.

\section{- Bilișsel Yöntem (Cognative-Code Method)}

Öğrencinin öğrenmenin merkezinde yer aldığı, öğretmenin rehber olduğu sözel, işitsel görsel pek çok araç kullanılan yöntem şeklinde özetlenebilir.

- İletişimsel Yöntem (Communicative Method)

Dil becerilerinin kendi doğal bağlamlarında ele alındığı ve iletişim kurmaya yönelik öğrenci odaklı bir yöntemdir.

- Seçmeli Yöntem (Eclectic Method)

Öğrencinin öğrenme ihtiyaçlarına göre öğretim programının belirlendiği ve motivasyonun ön planda olduğu bir öğretim yöntemidir.

- Telkin Yöntemi (Suggestopedia)

Sınıf ortamının hedef dilin özellikleri ve kuralları ile donatıldığı; öğrencilerin bu ortamda farkında olmadan öğrendikleri ve çevresel öğrenme tekniğinden (peripheral learning) yararlanılan bir yöntemdir.

Year 4/ 2020, Volume-4, Issue-5 | WwW.ispecjournal.org 


\section{- Danışmanlı (Grupla) Dil Öğretim Yöntemi (Community Language Learning)}

Hedef dilde yer alan kelime ve kalıpların telaffuzuna önem veren, ses kayıtları ve bilgisayar desteğinden yararlanılan, grup çalışması ağırlıklı bir yöntemdir.

\section{- Sessizlik Yöntemi (The Silent Way)}

Öncelikle okuma becerisini geliştirmeyi hedefleyen, renkler ve kodlamalarla öğretim yapılan bir yöntemdir.

\section{- Tüm Fiziksel Tepki Yöntemi (Total Physical Response)}

Hedef dilde verilen komutlarla beden dili, jest ve mimikler kullanılarak öğretim yapılan bir yöntemdir.

\section{- İşitsel-Görsel Yöntem (Audiovisual Method)}

Farklı duyu organlarına hitap edecek biçimde sözlü ve görsel ögelere yer veren alıştırmalara dayanan bir yöntemdir.

\section{- Görev Temelli Yöntem (Task-Based Method)}

Öğrencilere eğitimsel görevlerin verilerek, öğrenme sürecinden en iyi şekilde faydalanmasını amaçlayan bir öğretim yöntemidir.

- İçerik Merkezli Yöntem (Content-Based Method)

Hedef dilde yer alan konuların temel alındığı, hem kuralların hem de kullanımın öğrenilmesini hedefleyen bir yöntemdir.

\section{Web Destekli Öğretim}

Teknoloji temelli ortamlar, öğrenmede yer ve zamana bağlı kalmadan daha özgür bir öğrenme imkanı sunmaktadır. Teknoloji denildiğinde belki de akla gelen ilk şey olan bilgisayar, öğrenmeyi kolaylaştırır, öğrenci motivasyonuna ve öğrenmenin niteliğine olumlu katkılarda bulunur. Çünkü teknoloji, bireysel farklılıklara hitap eden, öğrenenlerin kendi öğrenmelerini şekillendirmelerine olanak sağlayan bir unsurdur. $\mathrm{Bu}$ konuda yapılmış araştırmalar incelendiğinde (Chou ve Wang, 2000; June, Chun-Sheng ve Chang 2003; Kettanurak, Ramamurthy ve Haseman, 2001; Pat, 2000) öğretim ortamlarında teknolojiden yararlanıldığ1 durumlarda öğrencilerin başarılarının, motivasyonlarının ve öğrenme sürecine ilişkin tutumlarının olumlu anlamda geliştiği belirlenmiştir.

Öğretimdeki araştırmalar, daha kısa sürede daha nitelikli öğrenmenin gerçekleştirilebileceği verimli öğrenme ortamlarının düzenlenmesinde odaklanmaktadır. $\mathrm{Bu}$ noktada bahsedilen öğretimin verimliliği, öğrenenlerin derste daha aktif olması, derse ve etkinliklere daha fazla 
katılım göstermesi ile yakından ilgilidir (Tezbaşaran, 1997). Web tabanlı eğitim ile geliştirilen sistem hem öğretmenin yükünü hafifletir hem de öğrenciye bireysel çalı̧̧ma alışkanlığı kazandırır. Web temelli eğitim ile bilgisayar temelli eğitim arasında benzerlik ve farklılıklar bulunmaktadır. Bu fark, internet kullanımı sayesinde sanal bir ortamın her türden ve her kesimden birey tarafından ulaşılabilir olmasıdır. (Özgür\&Tosun, 2010). Web tabanlı öğrenme, öğretenler için bir kolaylık olduğu gibi, öğrenenler için de bir motivasyon kaynağı görülmektedir.

"Web tabanlı öğretim ile web destekli öğretim çoğu kez birbirinin yerine geçecek şekilde veya eş anlamlı olarak kullanılmaktadır. Esasında web tabanlı öğretim ile web destekli öğretimin bazı ortak özellikleri bulunmaktadır. Web tabanlı öğretim ile web destekli öğretimin ortak özelliklerinden biri; bilgisayar destekli öğretimin tüm olanaklarını bünyesinde barındırmasıdır. Ortak özelliklerden bir diğeri; her iki öğretim yönteminde de derslerin, eş zamanlı (senkron) veya eş zamanlı olmayan (asenkron) şekilde işlenebilmesidir." (Öztürk, 2013).

Web tabanlı öğretim, öğrenciye bir derse ilişkin tüm içerikleri tek başına aktarabilen bir yol iken; web destekli öğretim sınıf içi öğretimin yanında kullanılan, geleneksel yöntemleri de destekleyebilen bir araçtır. Bununla birlikte web tabanlı öğretimin yönetilmesinde bir kişi yerine bir uzman grup olabilmektedir. Web destekli eğitimde ise öğretmen yönetim dahil tüm süreçleri bizzat yürüten kişidir. Eşgi (2006)' ye göre: “Web temelli öğretimde uygulamalar tamamen teknoloji temelli yapılırken, web destekli öğretimde yüz yüze devam eden öğretim, teknoloji ile tamamlanmaktadır. Web temelli öğretimde teknoloji, baskın olarak; web destekli öğretimde ise tamamlayıcı veya destekleyici olarak kullanılmaktadır”. Buna göre; web destekli eğitim, web destekli öğretimi de kapsamaktadır.

Web destekli eğitim, sınıf ortamı ile birlikle öğrenci ve öğretmenin teknolojik bir ortamda da buluşmasını sağlar. Bu sayede, etkileşim sağlanabilecek daha güncel ve yeni ortamlar yaratılır (Erişti, Şişman \& Yıldırım, 2008). Web destekli eğitim ortamında, geleneksel yöntemlerin aksine, öğretmenin anlatıp öğrencinin dinlediği ve tekrar ettiği bir yol değildir. Bu sistemde "öğrenci, öğretmenin belirlediği amaç ve yöntem doğrultusunda web destekli öğrenim sürecine dahil olur." (Erişti, Şişman \& Yıldırım, 2008). Ancak öğrenciler, internet ortamında aktif biçimde yaparak, yaşayarak, üreterek ve sorgulayarak öğrenme becerileri kazanırlar (MEB, 2002). 
Öğrenciler, kendi kişisel özellikleri ve ihtiyaçları doğrultusunda web destekli eğitim ortamlarından faydalandıklarında elde edilen öğrenme çıktıları da daha nitelikli ve kalıcı olmaktadır (Erişti, Şişman \& Yıldırım, 2008). Web destekli eğitim, yer ve zamandan bağımsız olarak öğrencilere güncellenebilir, çok yönlü ve kendi öğrenmelerinden sorumlu olacakları bir ortam sunmaktadır.

Öğrencilerin öğrenme süreçlerini zenginleştiren web destekli eğitim, artık daha önemli bir duruma gelmiştir (Kurubacak, 2005; akt Uzunboylu, 2002). Yapılandırmacı yaklaşımın ilkeleri ve günümüz koşulları düşünüldüğünde web destekli eğitim, eğitimin önemli bir parçası olmuştur (Ataizi, 2004). Web destekli eğitim, “isteğe bağlı ve öğrenci merkezli eğitim ve öğretim olanağı” (Kabakçı ve Karakaya, 2003) sağlamaktadır.

Öğretim programlarının öğrenciyi temel alarak geliştiği günümüzde Yapılandırmacı yaklaşımın özellikle ortaöğretim İngilizce ders kitaplarına yansıtılmaması, dolayısıyla öğrencilere bilgiyi keşfetme imkanı tanınmaması, geleneksel ders ortamlarının, öğrenciyi not kaygısına yöneltmesi ve öğrenme öğretme sürecini olumsuz etkilemesi; öğrencinin motivasyonunu ve derse olan ilgisini azaltması gibi olumsuzluklar klasik öğretim programının ihtiyaçları yeterli düzeyde karşılayamadığını göstermektedir. Bu anlamda farklı bir öğretim tasarımı olan web destekli öğretimin İngilizce dersine uyarlanmasının alana önemli katk1 sağlayacağı düşünülmektedir.

\section{Zihin Alışkanlıkları}

Zihin alışkanlıkları, bireylerin karşılaştıkları durumlar karşısında nasıl davrandıklarını gösteren; pek çok yetenek, ilgi, deneyim ve düşünme biçiminin birleşimidir. Costa ve Kallick (2000) tarafından belirlenen 16 zihin alışkanlığı vardır.Bunlar;

\section{Israrc1 olma}

2.Düşünceyi yönetebilme

3.Empati ile dinleme

4.Esnek düşünebilme

5.Düşünme üzerine düşünme (Üstbiliş)

6.Doğruluk için çaba gösterme 7.Sorgulama ve problem durumu yaratma

8.Geçmiş bilgileri yeni durumlarda kullanabilme 
9.Açık ve net biçimde düşünüp iletişim kurabilme

10.Bütün duyuları kullanarak veri toplayabilme

11. Üretme, hayal etme ve yenilikçi olma

12.Merak ve şaşkınlıkla karşılık verme

13.Sorumlu riskler alabilme

14.Mizah bulabilme

15.Birlikte düşünebilme

16.Sürekli öğrenmeye açık olma şeklinde belirlenmiştir (Costa \& Kallick, 2008).

$\mathrm{Bu}$ çalışma, Costa ve Kallick (2008)'in belirlediği ve Resim 1'de gösterilen 16 zihin alışkanlığından; farklı öğrenme stillerine sahip öğrencilerin yabancı dil öğrenirken başarı, motivasyon, hazır bulunuşluk ve öğrenmeye karsı tutumlarının olumlu bir şekilde geliştirilmesinde aktif rol oynayan (Demirel, 1990; Paker, 2006; Acat\&Demiral, 2002; Chou ve Wang, 2000; June, Chun-Sheng ve Chang 2003; Kettanurak, Ramamurthy ve Haseman, 2001; Pat, 2000; Reed, 1994) dört tanesinin kullanımına yönelik web destekli İngilizce öğretiminin 9. ve 10.sınıf öğrencilerinin tutumlarına ve akademik başarılarına etkisini göstermektedir.

$\mathrm{Bu}$ zihin alışkanlıkları;

- 1-Esnek Düşünme,

- 2-Tüm duyular aracilığıyla veri toplama,

- 3-Yaratma, Hayal Etme, Yenilik Getirme

- 4-Sürekli Öğrenme'dir.

\section{Araştırmanın Amacı}

Bu çalışmanın amacı, 9 ve 10. Sınıf İngilizce dersi öğretim programında yer alan "Nature and Environment" teması için tasarlanan zihin alışkanlıklarının kullanımına yönelik web destekli öğretim yaklaşımına uygun öğrenme ortamının, öğrenci tutumlarına ve akademik başarılarına olan etkisini araştırmaktır. Bu kapsamda aşağıdaki sorulara cevap aranmıştır: 
1. Öğrencilerin zihin alışkanlıklarının kullanımına yönelik web destekli öğretim öncesinde ve sonrasında İngilizce dersine yönelik tutum puanları nasıl bir dağılım göstermektedir?

2. Zihin alışkanlıklarının kullanımına yönelik web destekli öğretimin 9 ve 10.sınıf öğrencilerinin İngilizce dersine yönelik tutumlarına etkisi nedir?

3. Zihin alışkanlıklarının kullanımına yönelik web destekli öğretimin 9 ve 10.sınıf öğrencilerinin akademik başarılarına etkisi nedir?

\section{YÖNTEM}

$\mathrm{Bu}$ araştırmada nicel araştırma modeli temel alınmıştır. Nicel araştırmada, durum ve olaylar nesnelleştirilerek gözlemlenebilir, ölçülebilir ve sayısal olarak ifade edilebilir hale gelir. Nicel araştırmalar, kişilerin sosyal davranışlarını çeşitli yöntemlerle nesnel bir şekilde ölçerek sayısal verilerle açıklamayı hedefler (Akman, 2014). Araştırmada tek grup için tekrarlı ölçümler deseni kullanılmıştır. $\mathrm{Bu}$ desende ön test- son test şeklinde tutum ölçeği uygulanmıştır. Akademik başarıyı ölçmek için denel işlem öncesi ve sonrası başarı testi yapılmıştır. Burada amaç, deneklerin iki zaman arasındaki davranışlarında anlamlı bir farklılaşmanın meydana gelip gelmeyeceğini incelenmektedir (Büyüköztürk, 2016).

\section{Çalışma Grubu}

$\mathrm{Bu}$ çalışmada katılımcı grubunu, Ankara ili sınırları içinde bulunan Çankaya İlçesi Hasan Celal Güzel Anadolu İmam Hatip Lisesi'nde 2019-2020 eğitim öğretim y1lında 9 ve 10. Sınıfta okuyan öğrenciler oluşturmaktadır. Araştırmaya 36 öğrenci katılmıştır. Sınıflar ve öğrenciler random yöntemle seçilmiştir.

\section{Veri Toplama Araçları}

Araştırmada öğrencilerin derse yönelik olumlu olumsuz tutumlarını ölçebilmek için daha önceden geliştirilmiş geçerlik güvenirlik çalışmaları yapılmış tutum ölçeği kullanılmıştır. Tutum Ölçeği, "Yabancı Dil Hazırlık Eğitimi Alan ve Almayan Anadolu Lisesi Öğrencilerinin Yabancı Dil Özyeterlik Algılarının ve İngilizce Dersine Yönelik Tutumlarının İncelenmesi” adlı Burcu Hancı Yanar'a ait Yüksek Lisans Tezi’nde kullanılan tutum ölçeği izin alınarak kullanılmıştır. Ölçek 5'li Likert tipinde hazırlanmıştır. Ölçekte yer alan 30 maddenin faktör yükleri 0.51 ile 0.75 arasında değişiklik göstermektedir. Ölçeğin geneline ilişkin Cronbach Alpha güvenirlik katsayısı 0.95 olarak hesaplanmıştır (Hancı Yanar, 2008). 
Ayrıca denel işlem süresince yararlanılmak üzere, zihin alışkanlıklarının kullanımına yönelik bir web sitesi tasarımı yapılmıştır. Web sitesinin tasarımı sonunda 3 uzman görüşünden yararlanılmıştır. Web sitesi uzman görüşleri doğrultusunda geliştirilmiş ve güncellenmiştir. Uygulama öncesi ve sonrası akademik başarıyı ölçmek için başarı testi yapılmıştır. Başarı testi, web sitesinde yer alan içeriğe paralel olarak hazırlanmıştır.

\section{Denel İşlem:}

Öncelikle sınıfın fiziksel koşulları yeniden düzenlenmiş ve öğrencilerin ihtiyaçlarını karşılayacak; stres ve kaygıdan uzak hissetmeleri sağlayacak bir duruma getirilmiştir. Bu bağlamda; yüz yüze eğitim öğretim faaliyetlerinde okulun Drama ve Eleştirel Düşünce Atölyesi kullanılmıştır.

Web sitesinin renk seçiminde çevre temasına uygun sade ve sakinleştirici renkler tercih edilmiştir. Çünkü "web tasarımında renk, siteye sadece görsel bir çekicilik katmaz, aynı zamanda hedef kitleye (öğrenene) gönderdiği mesajdan ötürü de önemlidir” (Karataş, 2003). Derste kullanılacak ve öğrencilere dağıtılacak belge ve dokümanlar (çalışma kağıtları, resim, video, vb.), önceden hazırlanarak sırasıyla uygulanmıştır. Uygulama öncesi, gruba İngilizce dersine yönelik ön tutum testi uygulanmıştır.

Deney grubundaki öğrencilerle işbirlikli öğrenme ortamı ağılıklı olmak üzere; uygulama için geliştirilen web sitesi üzerinden web destekli etkinlikler, powerpoint sunumları, proje çalışmaları, mail yoluyla iletişim vb. etkinlikler yapılmıştır. Öğrenciler, derslerde öğrendiklerini bireysel olarak davranışa dönüştürmek ve zihin alışkanlıklarının kullanımına yönelik web destekli öğrenme sürecini sürdürmek amacıyla hazırlanan http://myecoteam.webnode.com internet sitesi üzerinden hem ders içeriği takip etmiş hem de görüşlerini paylaşmışlardır. Deney grubunda yer alan öğrenciler, öğrenme sürecinde (grup çalışmalarında ve diğer etkinliklerde) aktif rol almışlardır. Herhangi bir problemle karşılaş̧ıkları zaman, işbirliği yaparak bu problemi çözümlemeye çalışmışlar, gerektiğinde ise araştırmacıdan yardım istemişlerdir.

\section{Verilerin Analizi}

Verilerin çözümlenmesinde SPSS 15 paket programından yararlanılarak betimsel istatistikler ve bağımlı örneklem t-testi kullanılmıştır. 


\section{BULGULAR}

Bu bölümde sırasıyla alt amaçlara ait bulgulara yer verilmiştir. İlk sırada öğrencilerin İngilizce dersine yönelik tutum puanları ile ilgili betimsel istatistikler verilmiş, ön test ve son teste yönelik tutum puanlarının dağılımı incelenmiş; ardından İngilizce dersi için tasarlanan zihin alışkanlıklarının kullanımına yönelik web destekli öğretim yaklaşımına uygun öğrenme ortamının öğrencilerin İngilizce dersine yönelik tutumlarına ve akademik başarılarına etkisine bakılmıştır.

\section{1. Ö̆̆rencilerin İngilizce dersine yönelik ön test ve son test tutum puanlarının dă̆ılımına ilişkin bulgular}

Tablo 1'de öğrencilerin İngilizce dersine yönelik ön test ve son test tutum puanlarının dağılımı gösterilmiştir:

Tablo 1. Öğrencilerin Ingilizce dersine yönelik ön test ve son test tutum puanlarına dair betimsel istatistikler

\begin{tabular}{llllll}
\hline Ölçüm & N & Min. & Max. & X & Ss \\
\hline ÖNTEST & 36 & 30,00 & 135,00 & 68,6667 & 27,18508 \\
SONTEST & 36 & 75,00 & 150,00 & 126,1389 & 14,43241 \\
\hline
\end{tabular}

Tablo 1'de görüldüğü gibi 9 ve 10.sınıf öğrencilerinin İngilizce dersine yönelik tutumları ön testte ortalama $X=68,6667$ iken son testte $X=126,1389$ olarak belirlenmiştir. Tutum ölçeğinden alınabilecek alt $(X=30)$ ve üst $(X=150)$ puanlar dikkate alındığında ön teste yönelik puanların min. 30 - max.75 olduğu; son teste yönelik puanların ise min.135 - max.150 olduğu görülmektedir.

2. İngilizce dersi için tasarlanan web destekli öğretim yaklaşımına uygun öğrenme ortamının öğrencilerin İngilizce dersine yönelik tutumlarına etkisine ait bulgular

Tablo 2'de öğrencilerin İngilizce dersine yönelik ön test- son test tutum puanları arasında anlamlı bir fark olup olmadığına bakılmıştır.

Year 4/ 2020, Volume-4, Issue-5 | wWw.ispecjournal.org 
Tablo 2. Ingilizce dersi için tasarlanan web destekli öğretim yaklaşımına uygun öğrenme ortamının ögrencilerin İngilizce dersine yönelik tutumlarına etkisine ait t-testi sonuçları

\begin{tabular}{rllllll}
\hline Tutum Ölçümü & $\mathrm{N}$ & $\mathrm{X}$ & $\mathrm{Ss}$ & $\mathrm{Sd}$ & $\mathrm{t}$ & $\mathrm{p}$ \\
\hline Öntest & 36 & 68,6667 & 27,18508 & 35 & $-9,934$ & .000 \\
sontest & 36 & 126,1389 & 14,43241 & & & \\
\hline
\end{tabular}

Tablo 2'ye bakıldığında, öğrencilerin İngilizce dersine yönelik tutum puanlarının ortalaması ön test için $X=68,6667$; son test için $X=126,1389$ olarak bulunmuştur. Yapılan ttesti sonucunda öğrencilerin İngilizce dersine yönelik ön-son tutumları arasındaki farkın istatistiksel olarak anlamlı olduğu belirlenmiştir $[\mathrm{t}(35)=-9,934 ; \mathrm{p}<.01] . \mathrm{Bu}$ durumda araştırmanın katılımcıları olan 9 ve 10.sınıf öğrencilerinin web destekli İngilizce dersi öncesi ve sonrası İngilizce dersine ilişkin tutumları arasında anlamlı bir farklılık görülmektedir.

\section{3. İngilizce dersi için tasarlanan web destekli öğretim yaklaşımına uygun öğrenme} ortamının öğrencilerin akademik başarılarına etkisine ilişkin bulgular

Tablo 3'de İngilizce dersi için tasarlanan web destekli öğretim yaklaşımına uygun öğrenme ortamının öğrencilerin akademik başarılarına etkisine ilişkin bulgulara yer verilmiştir.

Tablo 3. Ingilizce dersi için tasarlanan web destekli öğretim yaklaşımına uygun ögrrenme ortamının öğrencilerin akademik başarılarına etkisine ilişkin bulgular

\begin{tabular}{lllllll}
\hline Ölçüm & $\mathrm{X}$ & $\mathrm{N}$ & $\mathrm{Ss}$ & $\mathrm{sd}$ & $\mathrm{t}$ & $\mathrm{p}$ \\
\hline $\begin{array}{l}\text { Başarı } \\
\text { Testi 1 } \\
\text { Başarı } \\
\text { Testi 2 }\end{array}$ & 72,4444 & 36 & 10,26073 & 35 & $-9,119$ & .000 \\
\hline
\end{tabular}

Yukarıdaki tabloya bakıldığında çalışma öncesi uygulanan başarı testine ait aritmetik ortalama $X=72,44$ olarak hesaplanırken; çalışmanın sonunda $X=81,47$ 'ye yükselerek olumlu bir değişim göstermiştir. Web destekli öğretim yaklaşımına uygun biçimde tasarlanan 
İngilizce dersine yönelik öğrenme ortamının, öğrencilerin akademik başarılarına olumlu etki sağladı̆̆1 görülmüştür, t(35)=-9,119; $\mathrm{p}<.01$.

\section{SONUÇ VE TARTIŞMA}

Ülkemizin yabancı dil öğretiminde ne yazık ki hedeflenen düzeye ulaşamaması uzun zamandır üstesinden gelinememiş bir sorundur. Bu sorunu en çok etkileyen olumsuzluklar; öğretmenlerin hala geleneksel yöntemlerle ders anlatması, sınıf mevcutlarındaki fazlalık, donanım eksiklikleri ve öğrencilerin bireysel özelliklerine gereken önemin verilmemesi şeklinde ifade edilebilir.

Yukarıda bahsedilen nedenler ve diğer pek çok olumsuz etkeni en aza indirmek amaciyla 9 ve 10.sınıf öğrencileriyle yapılan bu çalışmada, zihin alışkanlıklarının kullanımına yönelik web destekli öğretim yaklaşımına uygun öğrenme ortamının İngilizce dersine yönelik tutuma ve akademik başarıya etkisi incelenmiştir. Günümüzde eğitim anlayışı teknoloji odaklı olarak sürekli değişmekle beraber, eğitim kurumlarının bir çoğu kendi web destekli eğitim platformlarını oluşturmaktadır. İnternette; “web'in dev bir bilgi hazinesi olması, grafik desteği, kullanım kolaylığı, doküman, resim, müzik, animasyon ve video görüntülerinin bir arada kullanılabilmesiyle öğrenmeyi daha çekici hale getirmesi nedeniyle, web destekli eğitim son yıllarda oldukça önem kazanan çalışma alanlarından biri olmuştur.” (Şimşek vd., 2007).

$\mathrm{Bu}$ doğrultuda, öğrencilere ders kitapları dışında, ilgi ve ihtiyaçlarına uygun bir ortam yaratarak kısa sürede bile olumlu sonuçlar elde edilmesi amaçlanmıştır. Ayrıca literatürde yeterli sayıda çalışma olmayan zihin alışkanlıkları konusunun öğrenme ve öğretme sürecine olan olumlu etkilerini görmek hedeflenmiştir.

Deneysel çalışma öncesi ön test ve son test şeklinde tutum ölçeği yapılmış; altı hafta süren denel işlem öncesi ve sonrasında zihin alışkanlıklarının kullanımına yönelik web destekli öğretim materyalinin içeriğine paralel başarı testi uygulanmıştır. Yapılan analizler sonucunda öğrencilerin ön testte gösterdikleri tutum ve akademik başarı ortalama puanları ile son testte gösterdikleri tutum ve akademik başarılarının ortalama puanları karşılaştırılmış ve iki test arasında çalışmanın alt amaçları lehine anlamlı bir farklılık bulunmuştur. İngilizce dersine yönelik ön tutumların ortalaması $X=68,66$ iken, son tutum ortalama puanı $X=126,13$ olarak olumlu bir artış göstermiştir. Bu durum, İngilizce dersinde görsel açıdan daha zengin, öğrencilerin bireysel ihtiyaçlarına cevap veren, işbirlikli öğrenmenin daha yoğun 
gerçekleştirildiği yapılandırmacı ve zihin alışkanlıklarının kullanımına yönelik web destekli öğrenme ortamlarının öğrencilerin olumsuz tutumlarını değiştirebileceğini gösteren bir sonuçtur. Çalışmanın denel işlem süresinin kısa olmasının, akademik başarı sonuçlarının artışında etkili olabileceği düşünülmektedir. Uygulama öncesi $X=72,44$ olan ortalama başarı, altı haftalık uygulama sonrası $X=81,47$ puana yükselerek anlamlı bir fark meydana geldiğini göstermiştir.

9. ve 10.sınıf İngilizce dersi için tasarlanan zihin alışkanlıklarının kullanımına yönelik web destekli öğretimde, zihin alışkanlıklarının kullanımı ile öğrencilerin farklı kaynaklardan araştırmalar yaptığı, mümkün olduğunca duyularını da devreye sokarak düşünce ve yaratıcıklarını geliştirdikleri, güzel ürünler ortaya çıkarmak için sürekli çalıştıkları; web desteği sayesinde ise bireysel öğrenmelerinin ön plana çıktığı, her an her yerde öğretim felsefesinin hakim olduğu, sosyal medya kanallarıla desteklenen ve güncel bir hale gelen içeriğin, öğrenme ortamını zenginleştirdiği ve öğrenmenin daha etkili olmasını sağladığı görülmüştür. Çalışma sonunda, araştırmanın amacına ve alt amaçlarına uygun olumlu sonuçlar elde edilmiştir. Bunun nedeni öğrencilerin zihin alışkanlıklarının kullanımına yönelik web destekli öğrenme ortamında derse ilişkin olumlu tutumlarının daha çok gelişmesi ve kendi öğrenmelerinden daha aktif halde sorumlu olmaları şeklinde açıklanabilir. Bu sonuçların literatürde diğer disiplinler adına da olumlu örnekler teşkil edeceği düşünülmektedir. Uzunboylu'nun (2002) çalışmasıyla da desteklenen sonuçlara göre, "öğretim süreci içerisinde alternatif yöntemlerin geliştirilmesi ve kullanılması" gerekmektedir.

Alkan'1n (1997; akt Gömleksiz \& Sertdemir Düşmez, 2005) bilgisayar destekli İngilizce öğretimi ve öğretmen merkezli İngilizce öğretimine ilişkin yapmış karşılaştırmada, bilgisayar destekli öğretimin öğrenim gören öğrencilerin daha üretken ve aktif olduğu saptsnmıştır. Aytürk (1999; akt Gömleksiz \& Sertdemir Düşmez, 2005) de bilgisayar destekli öğretimin öğrencilerin derse ve bilgisayara karşı tutumlarını olumlu etkilediğini belirtmiştir.

$\mathrm{Bu}$ araştırma sonucuna göre aşağıdaki önerilerin literatüre katkı sağlayacağı düşünülmektedir;

Zihin alışkanlıklarının kullanılmasına yönelik web destekli öğretimin sadece İngilizce dersinde değil diğer derslerde de uygulanması ile elde edilecek sonuçlar literatüre önemli katk1 sağlayacaktır. 
$>\mathrm{Bu}$ çalışmada yabancı dil öğretiminde daha fazla etkisi olduğu düşünülen 4 zihin alışkanlığı üzerinde durulmuştur. 16 zihin alışkanlığını kapsayan daha geniş kapsamda çalışmalar yapılması literatürdeki boşluğu doldurabilir.

> Zihin alışkanlıklarının öğrenme sürecine etkisi konusunda literatürde yer alan Matematik, Geometri ve Fen Bilimleri alanı dışında diğer disiplinlerde çalışmalar gerçekleştirilebilir.

> Özellikle içinde bulunduğumuz Covid-19 pandemi süreci de göz önüne alındığında; Web tabanlı ya da destekli öğrenme ortamlarının eğitim-öğretim faaliyetlerinde kullanılması çok faydalı olacaktır.

> Web tabanlı veya destekli öğrenme ortamlarının eğitim-öğretim sürecine yaptıkları pozitif etki düşünülürse, özellikle her daim güncel olması beklenen dil eğitiminde kullanılması yararlıdır.

$>$ Öğretime yönelik daha fazla web sitesi hazırlanması ve bu web sitelerinin kullanımının yaygınlaştırılması için gereken faaliyetlerin artırılması ve öğretmenlere ücretsiz web sitesi kurma imkanı veren adreslerin tanıtılması bu tür öğretim faaliyetlerinin artmasını sağlayacaktır. Bu konuda hizmet içi eğitimler düzenlenebilir.

> $\mathrm{Bu}$ çalışmada İngilizce dersi müfredatında yer alan bir tema ele alınmıştır. Farklı temaları içeren daha zengin web destekli öğrenme ortamlarının yaratılması sonuçların daha genellenebilir olmasını sağlayacaktır.

\section{KAYNAKÇA}

1. Acat, B. ve Demiral, S. (2002) Türkiye'de Yabancı Dil Öğreniminde Motivasyon Kaynakları ve Sorunları, Kuramdan Uygulamaya Eğitim Yönetimi Dergisi, 8 (31), 312-329.

2. Akman, G.N. (2014) Nicel ve Nitel Araştırma Yöntemleri Ders Notları, Afyon Kocatepe Üniversitesi, Afyonkarahisar. 20.12.2016 tarihinde http://docplayer.biz.tr/6184019-Nicel-ve-nitel-arastirma-yontemleri.html web sitesinden alınmıştır.

3. Arslan, A. (2008) Web Destekli Öğretimin Ve Öğretimsel Materyal Kullanımının Öğrencilerin Matematik Kaygısına, Tutumuna Ve Başarısına Etkisi, Marmara Üniversitesi; Doktora Tezi, İstanbul. 
4. Ataizi, M. (2004). Web Destekli Eğitimde Öğrenme Çıktılarının Değerlendirilmesi, 4. Uluslararası Eğitim Teknolojileri Sempozyumu, 24-26 Kasım 2004, Sakarya, Türkiye, Vol:2, 1279-1283.

5. Atay, D. (2004) İngilizce Öğretmenlerinin Motivasyon Stratejileri, Hasan Ali Yücel Eğitim Fakültesi Dergisi, Say1 1, 99-108.

6. Aydoğan, İ. ve Çilsal, Z. (2007) Yabancı Dil Öğretmenlerinin Yetiştirilme Süreci (Türkiye Ve Diğer Ülkeler), Sosyal Bilimler Enstitüsü Dergisi, 22(1), 179-197.

7. Bağçeci, B. (2004) Ortaöğretim Kurumlarında İngilizce Öğretimine İlişkin Öğrenci Tutumları (Gaziantep İli Örneği), XIII. Ulusal Eğitim Bilimleri Kurultayl, 6-9 Temmuz İnönü Üniversitesi, Eğitim Fakültesi, Malatya.

8. Büyüköztürk, Ş. (2016) Sosyal Bilimler İ̧̧in Veri Analizi El Kitabl, Pegem Akademi Yayınc1lık, Ankara.

9. Cengizhan, S. (2007) Proje Temelli Ve Bilgisayar Destekli Ögretim Tasarımlarının; Bagımlı, Bagımsız ve İş Birlikli Ögrenme Stillerine Sahip Ögrencilerin Akademik Basarılarına Ve Ögrenme Kalıcılıgına Etkisi Türk Egitim Bilimleri Dergisi, 5(3), 377401.

10. Chou, H.W. Ve Wang, T.B. (2000). The Influence Of Learning Style And Training Method On Self-Efficacy And Learning Performance in www Home Page Design Training, International Journal Of Information Management, 20(6), 455-472

11. Costa, A.L. \& Kallick, B. (2000). Habits of mind: A developmental series. http://www.chsvt.org/wdp/Habits_of_Mind.pdf sayfasından erişilmiştir.

12. Costa, A.L. \& Kallick, B. (2000). Describing 16 habits of mind. http://www.ccsnh.edu/sites/default/files/content/documents/CCSNH\%20MLC\%20HA BITS\%20OF\%20MIND\%20COSTA-KALLICK\%20DESCRIPTION\%201-8-10.pdf sayfasından erişilmiştir.

13. Costa, A.L. \& Kallick, B. (2008). Learning and leading with habits of mind: 16 essential characteristics for success. Alexandria, VA: Association for Supervision and Curriculum Development.

14. Çelebi, M. D. (2006) Türkiye'de Anadili Eğitimi ve Yabancı Dil Öğretimi, Sosyal Bilimler Enstitüsü Dergisi, 21(2), 285-307.

15. Çelen, İ. ve Akar Vural, R. (2009) Eğitimde Drama ve İngilizce Öğretimi: İlköğretim Dördüncü Sınıf Öğrencileri Üzerine Bir Araştırma, Illköğretim Online, 8(2), 425-438. 
16. Ergür, D.O. (2002) Yabancı Dil Öğreniminde Motivasyon Kaynakları, Eğitim ve Bilim Dergisi, 126 (27), 38-42.

17. Erişti, S.D. ; Şişman, E. ve Yıldırım, Y. (2008) İlköğretim Branş Öğretmenlerinin Web Destekli Öğretim ile ilgili Görüşlerinin İncelenmesi, İlköğretim Online, 7(2), 384-400.

18. Eşgi, N. (2006). Web Temelli Öğretimde Basılı Materyal Ve Yüzyüze Öğretimin Öğrenci Başarısına Etkisi, Türk Ĕgitim Bilimleri Dergisi, Cilt:4, Sayı:4, Ankara.

19. Gömleksiz, M.N. ve Sertdemir Düşmez O. (2005) İngilizce'de Relative Clause Konusunun Öğretiminde Bilgisayar Destekli Öğretim İle Geleneksel Yöntemin Öğrenci Başarısı Üzerine Etkisinin Karşılaştırılması, Türk Eğitim Bilimleri Dergisi, 3(2), 163-179.

20. Hancı Yanar, B. (2008). Yabancı Dil Hazırlık Eğitimi Alan Ve Almayan Anadolu Lisesi Öğrencilerinin Yabancı Dil Özyeterlik Algılarının Ve İngilizce Dersine Yönelik Tutumlarının İncelenmesi, Yüksek Lisans Tezi, Ege Üniversitesi, İzmir.

21. Haznedar, B. (2010) Türkiye'de Yabanc1 Dil Eğitimi: Reformlar, Yönelimler ve Öğretmenlerimiz, International Conference on New Trends in Education and Their Implications, 11-13 November, Antalya.

22. June, L.; Chun-Sheng, Y. Ve Chang, L. (2003). Learning Style, Learning Patterns And Learning Performance İn A Webc1-Based Mis Course, Information\&Management, 40(6), 497-507.

23. Kabakçı, I., Karakaya, Z. (2003). Web’de Öğrenme, Ölçme ve Değerlendirme, Türkiye Bilişim Derneği, Ankara.

24. Karataş, S. (2003) Öğretim Amaçlı Web Sayfası Tasarımında Renk Kullanımı, G. $\ddot{U}$. Gazi Eğitim Fakültesi Dergisi, 23(2), 139-148.

25. Kettanurak, V.; Ramamurthy , K. Ve Haseman, W. D. (2001). User Attitude As A Mediator Of Learning Performance Improvement In An Interactive Multimedia Environment: An Empirical Investigation Of The Degree Of Interactivity And Learning Styles, International Journal Of Human-Computer Studies, 54(4). 541-583.

26. MEB (2002). Öğretmen Yeterlikleri, Ankara: Meb Öğretmen Yetiştirme ve Eğitimi Genel Müdürlüğü, Milli Eğitim Basımevi. 
27. Memiş, M.R. ve Erdem, M.D. (2013) Yabancı Dil Öğretiminde Kullanılan Yöntemler, Kullanım Özellikleri Ve Eleştiriler, Turkish Studies - International Periodical For The Languages, Literature and History of Turkish or Turkic, 8(9), 297-318

28. Özgür, H. ve Tosun, N. (2010) Internet Destekli Eğitimin E-Öğrenme Tutumlarına Etkisi, Internet Teknolojileri Derneği XV.Türkiye'de Internet Konferansı, 2-4 Aralık 2010, İstanbul.

29. Öztürk, D. (2013) Web Destekli Öğretimin Öğrencilerin Mesane Kateterizasyonunu Öğrenmelerine Etkisi, Doktora Tezi, Hacettepe Üniversitesi, Ankara.

30. Paker, T. (2006) Çal Bölgesindeki Okullarda İngilizce Öğretiminin Sorunları Ve Çözüm Önerileri, Çal Sempozyumu, 1-3 Eylül, Denizli.

31. Pat, A. F. (2000). Learning Styles And Student Attitudes Toward Various Aspects Of Network-Based Instruction, Computers in Human Behavior, 16(4), 359-379.

32. Reed, W. M. (1994). The Relationship Between The Learning Strategies And Learning Styles N A Hypermedia Environment, Computers in Human Behavior, $10(4), 419-434$.

33. Soyupek, H. (2007) Yabancı Dil Öğretiminde Güdülemenin Önemi, Uluslar arası Asya ve Afrika Çalışmaları Kongresi, ICANAS 38. 10-15 Eylül, Ankara.

34. Şimşek, A.; Özdamar, N.; Beçit, G.; Kılıçer, K.; Akbulut, Y. ve Yıldırım, Y. (2007) Türkiye'deki Eğitim Teknolojisi Araştırmalarında Güncel Eğilimler, Selçuk Üniversitesi Sosyal Bilimler Dergisi, 19, 439-458.

35. Tezbaşaran, A. A. (1997). Öğretim Ve Öğrenmede Bilgisayara Dayalı Bilgi Teknolojileri, Tübitak Bilim Ve Teknik Dergisi, 355, 54.

36. Tok, H. ve Arıbaş, S. (2008) Avrupa Birliğine Uyum Sürecinde Yabancı Dil Öğretimi, Inönü Üniversitesi Eğitim Fakültesi Dergisi, 15(9), 205-227.

37. Uzunboylu, H. (2002) Web Destekli İngilizce Öğretiminin Öğrenci Başarıs1 Üzerindeki Etkisi, Doktora Tezi, Ankara Üniversitesi, Ankara. 